NASZA DERMATOLOGIA Online OUR DERMATOLOGY Online

Source of Support:

Nil

Competing Interests:

None

\section{EPONYMS IN THE DERMATOLOGY LITERATURE LINKED TO DENMARK}

\author{
Khalid Al Aboud ${ }^{1}$, Daifullah Al Aboud ${ }^{2}$ \\ ${ }^{1}$ Department of Public Health, King Faisal Hospital, Makkah, Saudi Arabia \\ ${ }^{2}$ Dermatology Department, Taif University, Taif, Saudi Arabia
}

Corresponding author: Dr. Khalid Al Aboud

amoa65@hotmail.com
Denmark, officially the Kingdom of Denmark, as it is known, is a state in the Scandinavian region of Northern Europe. The estimated population is around ,5,580,413. The national language is Danish [1].

Denmark has one of the world's highest per capita income. For 2013, Denmark is listed 15th on the Human Development Index.Danish engineers are world-leading in providing diabetes care equipment and medication products [1].

The most famous medical eponyms linked to Denmark are The Bartholin glands and Hirschsprung disease.

The Bartholin glands are two glands located slightly posterior and to the left and right of the opening of the vagina They were first described in 1677, by the Danish anatomist Caspar Bartholin the Younger (1655-1738) [2]. Some sources mistakenly ascribe their discovery to his grandfather, theologian and anatomist Caspar Bartholin the Elder (1585-1629).

Gaspard Bartholin had the good fortune during his stay in
Paris to meet Joseph Guichard du Verney, a French anatomist who had discovered the glandula vestibuloris major. Back in Copenhagen he was appointed professor of anatomy. At the age of 21, he described the physiology of the glandula vestibuloris major, later known as Batholin's gland. Ennobled, laden with honours, he was later appointed personal physician to the king of Denmark until his death in 1738 [2].

Hirschsprung disease is a developmental disorder of the enteric nervous system and is characterized by an absence of ganglion cells in the distal colon resulting in a functional obstruction. The first report of Hirschsprung disease dates back to 1691, however, the disease is named after Harald Hirschsprung (18301916), the Danish physician who first described two infants who died of this disorder in 1888 [3].

In Table I [4-9], we highlighted on selected eponyms in dermatology literature, linked to Denmark.

\begin{tabular}{|c|l|}
\hline $\begin{array}{c}\text { Eponyms in the dermatology } \\
\text { literature linked to Denmark }\end{array}$ & \multicolumn{1}{c|}{ Remarks } \\
\hline Asboe-Hansen sign [4-6] & $\begin{array}{l}\text { The Asboe-Hansen sign (also known as ,indirect Nikolsky sign” refers to the extension of a } \\
\text { blister to adjacent unblistered skin when pressure is put on the top of the bulla. } \\
\text { This sign is named for Gustav Asboe-Hansen (1917-1989), (Fig. 1), who was a Professor } \\
\text { and Head of the Department of Dermatology and Venereology at the University Hospital in } \\
\text { Copenhagen, Denmark. His article was published in 1960. } \\
\text { Asboe-Hansen noticed the differences between the blister-spread patterns in pemphigus and } \\
\text { those in bullous pemphigoid. Whereas in pemphigus vulgaris, the blister extension had a sharp } \\
\text { angle, in bullous pemphigoid, the advanced border was rounded as in a pressure bulla. } \\
\text { Nikolsky's sign is named for, Russian dermatologist Pyotr Vasiliyevich Nikolskiy (1858-1940). }\end{array}$ \\
\hline Ehlers-Danlos syndrome (EDS) [7] & $\begin{array}{l}\text { Also known as Cutis hyperelastica, is a group of inherited connective tissue disorders, caused by } \\
\text { a defect in the synthesis of collagen. } \\
\text { Named after Edvard Laurits Ehlers (1863-1937), (Fig. 2), who was a Danish dermatologist and } \\
\text { the Mayor of Copenhagen's son, and Henri-Alexandre Danlos (1844-1912), who was a French } \\
\text { physician and dermatologist. }\end{array}$ \\
\hline
\end{tabular}




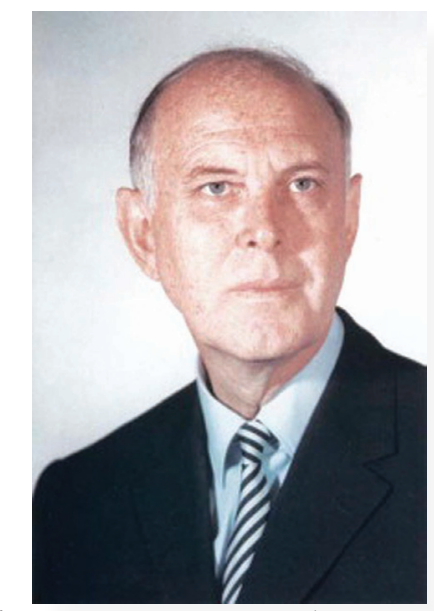

Figure 1. Gustav Asboe-Hansen (1917-1989)

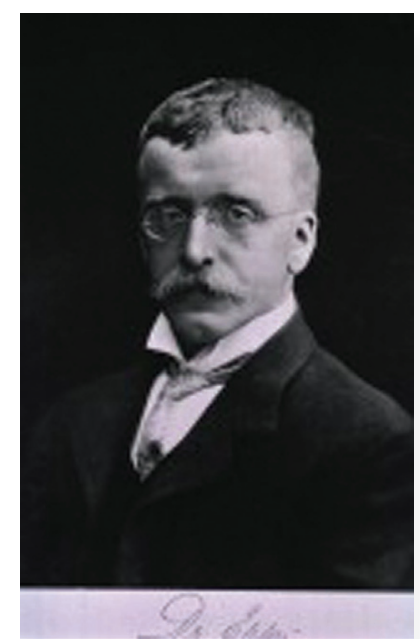

Figure 2. Edvard Laurits Ehlers (1863-1937). A courtesy of National Library of Medicine.

\begin{tabular}{|c|l|}
\hline $\begin{array}{c}\text { Eponyms in the dermatology } \\
\text { literature linked to Denmark }\end{array}$ & \multicolumn{1}{c|}{ Remarks } \\
\hline Rud syndrome $[8,9]$ & $\begin{array}{l}\text { This rare syndrome is characterized by ichthyosis, obesity, hypogonadism, oligophrenia (defined } \\
\text { as less-than-normal mental development), epilepsy, and endocrinopathies. It is named after, Einar } \\
\text { Rud, who was a Danish physician, born in 1892. However, the existence of this entity has been } \\
\text { questioned. }\end{array}$ \\
\hline Table I. Selected Eponyms in the dermatology literature linked to Denmark (continued)
\end{tabular}

\section{REFERENCES}

1. Denmark. Wikipedia ${ }^{\circledR}$ [Internet]. Wikimedia Foundation. [Updated 14 May 2013; cited 14 May 2013]. Available from: http:// en.wikipedia.org/wiki/Denmark

2. Bouchet A: [Gaspard II Bartholin and the vulvovaginal gland]. Ann Chir. 2000;125:483-8.

3. Roed-Petersen K, Erichsen G: The Danish pediatrician Harald Hirschsprung. Surg Gynecol Obstet 1988;166:181-5.

4. Al Aboud K, Al Aboud A: Eponyms in the dermatology literature linked to Russia. Our Dermatol Online. 2013;4(Suppl. 1):414-5.
5. Grando SA, Grando AA, Glukhenky BT, Doguzov V, Nguyen VT, Holubar K: History and clinical significance of mechanical symptoms in blistering dermatoses: a reappraisal. J Am Acad Dermatol. 2003;48:86-92.

6. Asboe-Hansen G: Blister-spread induced by finger-pressure, a diagnostic sign in pemphigus. J Invest Dermatol. 1960;34:5-9.

7. Scully C, Langdon J, Evans J: Marathon of eponyms: 5 EhlersDanlos syndrome. Oral Dis. 2009; 15:517-8.

8. Al Aboud K, Al Aboud D: Einar Rud and the syndrome that bears his name. Eur J Dermatol. 2011;21:1025-6.

9. Happle R: Rud syndrome does not exist. Eur J Dermatol. 2012;22:7.

Copyright by Khalid Al Aboud, et al. This is an open access article distributed under the terms of the Creative Commons Attribution License, which permits unrestricted use, distribution, and reproduction in any medium, provided the original author and source are credited. 